\title{
Capsicum Species: Symptomless Hosts and Reservoirs of Tomato yellow leaf curl virus
}

\author{
J. E. Polston, L. Cohen, T. A. Sherwood, R. Ben-Joseph, and M. Lapidot
}

First and third authors: Department of Plant Pathology, University of Florida, Gainesville 32611; second, fourth, and fifth authors: Department of Genetics and Vegetables, ARO Volcani Center, Bet Dagan, 50250, Israel.

Accepted for publication 18 January 2006.

\begin{abstract}
Polston, J. E., Cohen, L., Sherwood, T. A., Ben-Joseph, R., and Lapidot, M. 2006. Capsicum species: Symptomless hosts and reservoirs of Tomato yellow leaf curl virus. Phytopathology 96:447-452.

Five Capsicum species were tested for susceptibility to Tomato yellow leaf curl virus (TYLCV) and the mild strain of TYLCV (TYLCV-Mld). TYLCV was able to infect 30 of 55 genotypes of $C$. аппиит, one of six genotypes of $C$. chinense, one of two genotypes of $C$. baccatum, and the only genotype of $C$. frutescens tested but was unable to infect the one

differences were observed between the Israeli and Florida isolates of TYLCV. None of the Capsicum species showed symptoms after infection with TYLCV or TYLCV-Mld. TYLCV was detected in fruits of C. annиum, but whiteflies were unable to transmit virus from fruits to plants. Whiteflies were able to transmit both TYLCV and TYLCV-Mld from infected pepper plants to tomato plants. Pepper plants in research plots were found infected with TYLCV at rates as much as $100 \%$. These data demonstrate the ability of some genotypes of pepper to serve as reservoirs for the acquisition and transmission of TYLCV and TYLCV-Mld.
\end{abstract} genotype of $C$. pubescens tested. This is the first evidence for the susceptibility of $C$. baccatum, $C$. chinense, and $C$. frutescens to TYLCV. Unlike TYLCV isolates, TYLCV-Mld was unable to infect $C$. chinense. No host
Additional keywords: begomovirus, ecology, epidemiology, geminivirus, pepper.
Tomato yellow leaf curl virus (TYLCV) (family Geminiviridae, genus Begomovirus) is a plant virus first observed in infected tomato plants (Lycopersicon esculentum Mill.) in the eastern Mediterranean more than 70 years ago $(4,5,10)$. TYLCV is readily transmitted in a persistent manner by Bemisia tabaci Genn., one biotype that is also known as B. argentifolii (Bellows and Perring). TYLCV is readily acquired by both immature and adult whiteflies, can be transmitted at relatively high efficiencies, and is retained for up to the lifespan of the adult whitefly $(5,11)$.

A mild and a severe strain of TYLCV have been identified, and their DNA sequences are $94 \%$ identical. The mild isolate (TYLCV-Mld) occurs in Israel and Spain $(2,14)$ and is somewhat of a misnomer because the symptoms it causes in tomato are nearly indistinguishable from those of the severe strain of TYLCV. The severe strain is the result of a recombination event between TYLCV-Mld and another, as yet undescribed, begomovirus similar to Tomato leaf curl virus (ToLCV) (16). The severe strain is more widely distributed and is the strain found in the Caribbean and southeastern United States. $(13,19,27,29)$.

TYLCV is primarily known as a pathogen of tomato. TYLCV symptoms in tomato are severe, and consequently, the virus can devastate tomato production $(1,5,18)$. TYLCV also can have severe impact on bean production (15). Management of TYLCV is difficult, often requiring significant changes in production and management practices as well as yield expectations (8). Although the vector has a large number of feeding and breeding hosts, the virus has a narrower host range (4). The identification of alternative hosts of TYLCV is important for the development of effective management practices (28).

There are conflicting reports regarding the susceptibility of peppers (Capsicum spp.) to TYLCV. Greenhouse inoculation

Corresponding author: J. E. Polston; E-mail address: jep@ufl.edu

DOI: 10.1094/PHYTO-96-0447

(C) 2006 The American Phytopathological Society studies with TYLCV isolates from Jordan (11) and Israel (S. Cohen, personal communication) indicated that $C$. annuum L. was not a host, with lack of infection confirmed by back-transmission through grafting. In Spain, C. annuum was reported as a host of an uncharacterized strain of TYLCV (21). The lack of discriminating nomenclature (until recently) among TYLCV-like viruses added to the confusion (reviewed by Moriones and Navas-Castillo [13]). There have been reports of the detection of TYLCV in field plants of C. annuum in Cuba and the Dominican Republic using PCR followed by restriction analysis and nucleic acid spot hybridization, respectively $(20,23,24)$. However, these findings were not confirmed by transmission studies. Only one study reports C. chinense Jacquin to be a host of TYLCV and this was on the basis of nucleic acid hybridization of samples collected from field plants (23). The host status of $C$. baccatum var. microcarpum (DC) Hassl, C. frutescens L., and C. pubescens Ruiz \& Paz. has not been reported. Recently, Morilla et al. (12) demonstrated that C. annuum plants could be infected with two strains of TYLCV, TYLCV-Mld[ES01/99] and TYLCV-[Alm], and that infected plants were symptomless. In addition, their studies showed that whiteflies were unable to acquire and transmit the virus from these plants, and they concluded that pepper was a dead end host for TYLCV (12).

To gain a more thorough understanding, we conducted studies to evaluate the susceptibility of genotypes of five species of Capsicum to TYLCV and TYLCV-Mld. We further tested whether whiteflies can acquire TYLCV and TYLCV-Mld from either infected plants or fruit, and whether pepper plants were able to serve as reservoirs of TYLCV and TYLCV-Mld.

\section{MATERIALS AND METHODS}

Sources of cultures. Whiteflies (Bemisia tabaci, biotype B) used in this study were adult populations of mixed age and gender. Whiteflies were reared on healthy or TYLCV-infected tomato plants or on cotton plants grown in muslin-covered cages maintained within an insect-proof greenhouse. 
The Volcani TYLCV culture was derived from the original culture first described by Cohen and Nitzany (5) that was a mixture of two TYLCV strains, TYLCV, described by Navot et al. (17) (GenBank Accession No. X15656) and TYLCV-Mld, described by Antignus and Cohen (2) (GenBank Accession No. X76319). Each strain was maintained separately in tomato and located in different greenhouses. The Florida TYLCV culture (GenBank Accession No. AY530931) is $98.3 \%$ identical to TYLCV (GenBank Accession No. X15656) (17). Cultures were maintained in tomato by whitefly transmission.

Inoculation of TYLCV to test plants by whiteflies. Pepper test plants were inoculated at the two- to four-true-leaf stage of development in a growth chamber $\left(23\right.$ to $25^{\circ} \mathrm{C}, 13$-h light $)$ in whitefly-proof cages. Whiteflies were either reared on virus-infected tomato plants or cotton (Gossypium hirsutum L.) and then given a 48-h acquisition access period (AAP). The number of whiteflies used per plant and the length of the inoculation access period (IAP) varied among experiments. After inoculation, test plants were placed in whitefly-proof cages in a greenhouse. All plants were evaluated for symptoms at 4 to 6 weeks after treatment with imidacloprid (Bayer Cropscience, Research Triangle Park, NC). At the same time, the youngest leaves of test plants were sampled for laboratory assay. Noninoculated control plants were maintained in an isolated insect-proof greenhouse or cage (to prevent contamination) and treated with imidacloprid. Cultivars in which all plants could not be infected by either inoculation density were considered resistant to TYLCV.

Viral DNA detection: Florida. Nucleic acid spot hybridization assays were used to determine infection of plants. Young leaves from control and test plants were collected and extracted using a leaf squeezer (Ravenel Specialities, Seneca, SC). A 20- $\mu$ l sample was taken from the expressed sap and added to $140 \mu \mathrm{l}$ of TE buffer (10 mM Tris-acetate, $\mathrm{pH} 8.0$, and $1 \mathrm{mM}$ EDTA, $\mathrm{pH} 8.0$ ). Twenty microliters of $1 \mathrm{M} \mathrm{NaOH}$ was added to the diluted sap, and the contents were mixed and incubated at room temperature for $10 \mathrm{~min}$. Extracts were then neutralized with $20 \mu \mathrm{l}$ of $2 \mathrm{M}$ sodium acetate, $\mathrm{pH}$ 5.2. The contents were mixed and incubated at room temperature for $10 \mathrm{~min}$. Following centrifugation, supernatants of the extracted samples were spotted in $20-\mu$ l aliquots into TAE (40 mM Tris-acetate, $1 \mathrm{mM}$ EDTA, pH 8.0) wetted Nytran membranes (Schleicher and Schull, Inc. Keene, NH) using a blotting manifold (Hybrid-Dot Manifold; Life Technologies, Inc., Gaithersburg, MD). Membranes were air dried and then baked at $65^{\circ} \mathrm{C}$ for $30 \mathrm{~min}$. TYLCV DNA was detected using a 312-bp fragment clone obtained from the intergenic region of an Egyptian strain of TYLCV (nucleotides 2616 to 146) labeled with ${ }^{32} \mathrm{P}$ using an Amersham High Prime Labeling System (Amersham, Arlington Heights, IL). The probe was hybridized to the blots at $65^{\circ} \mathrm{C}$ overnight and rinsed under high stringency conditions. Blots were exposed to film for 8 to $48 \mathrm{~h}$.

Polymerase chain reaction (PCR) was used to confirm the presence of TYLCV. Primers used for TYLCV detection were one of two degenerate pairs, PAL1v1978 and PAR1c496 (22) or V324 and C889 (3). The following PCR conditions were utilized for primer set PAL1v1978 and PAR1c496: initial denaturation at $94^{\circ} \mathrm{C}$ for $2 \mathrm{~min}$, followed by 35 cycles of denaturation at $94^{\circ} \mathrm{C}$ for $30 \mathrm{~s}$, primer annealing at $55^{\circ} \mathrm{C}$ for $35 \mathrm{~s}$, elongation at $72^{\circ} \mathrm{C}$ for 1.25 min with $2 \mathrm{~s}$ added to each cycle, and a final elongation period at $72{ }^{\circ} \mathrm{C}$ for $7 \mathrm{~min}$. PCR conditions were followed as described (30) for primer set V324 and C889.

Volcani. Viral DNA was detected in the upper leaves of the infected pepper plants either by using dot blot hybridization or PCR. For dot blot hybridization, leaf tissue $(0.1 \mathrm{~g})$ from the plant apex was ground in $0.5 \mathrm{ml}$ of $0.4 \mathrm{M} \mathrm{NaOH}$ and $10-\mu \mathrm{l}$ aliquots were spotted onto a nylon membrane as described previously (9). TYLCV DNA served as the template for the production of an in vitro-synthesized ${ }^{32} \mathrm{P}$-labeled viral riboprobe corresponding to the full-length viral genome as described previously (9).
TYLCV and TYLCV-Mld DNA were detected in inoculated pepper plants using PCR with two sets of strain specific primers. Total nucleic acids were extracted from the apex of test plants (7) and served as templates for PCR amplification as described previously (9). TYLCV was detected using primers TYC1F and TYISM3 (5'-TTG/AGG/GAC/ACC/GAT/TCA/TTT/C-3', nucleotides 25 to 4) that amplified a 725-nt DNA fragment from TYLCV but not TYLCV-Mld. TYLCV-Mld was detected using primers TYV1R (5'-GAA/TCA/TAG/AAA/TAG/ATG/CGT/GTT$3^{\prime}$, nucleotides 1243 to 1219 ) and TYMM2 (5'-CAA/TGA/GTA/CCG/ATT/GAC/CAA/C-3', nucleotides 6 to 27 ) that amplified a 1,237-nt DNA fragment from TYLCV-Mld, but not TYLCV. Primer sequences were based on the published sequence of TYLCV (GenBank Accession No. X15656) and TYLCV-Mld (GenBank Accession No. X76319).

Transmission from infected peppers to tomato. Transmission assays of TYLCV from infected pepper plants to healthy tomato plants were performed using infected plants of $C$. annuum 'California Wonder', C. baccatum, C. chinense 'Guam Boonies', and C. frutescens 'Tabasco green leaf hot'. One hundred nonviruliferous whiteflies were placed on test plants that tested positive for TYLCV using PCR and placed in whitefly-proof cages in a greenhouse. The whiteflies were given a 2- to 3-day AAP on the infected pepper plants, after which time a 4-week-old tomato plant (two-true-leaf stage) was placed in the cage. Three weeks after the addition of whiteflies, the tomato plant was examined for symptoms of TYLCV infection and was tested for the presence of TYLCV using PCR. Transmission was considered successful when tomato plants displayed symptoms characteristic of TYLCV and tested positive for TYLCV using either nucleic acid spot hybridization or PCR.

Determining transmission efficiency. The ability of pepper plants to serve as acquisition hosts of TYLCV was compared with that of tomato. Nonviruliferous whiteflies were allowed a 48- to 72-h AAP on 'California Wonder' pepper plants that tested positive for TYLCV using PCR. Following the AAP, whiteflies were allowed an IAP on tomato test plants by two methods, clip cage and 'free choice'. Inoculation with clip cages-following the AAP, 10 whiteflies were placed in each clip cage, and then one clip cage was attached onto the second leaf from the apex of each tomato test plant (two- to three-true-leaf stage). Whiteflies were allowed a 48-h IAP on tomato test plants. Inoculation by free choice-following the AAP, the virus source plant was removed and tomato plants (two- to three-true-leaf stage) were added to the cage allowing whiteflies a 48- to 72-h IAP at a density of 25 to 50 whiteflies per plant. Regardless of inoculation methods, following the IAP, plants were treated with imidacloprid to remove whiteflies and kept in an insect-proof cage for 4 weeks at which time they were evaluated for development of symptoms of TYLCV. The experiments comparing pepper and tomato plants were conducted four separate times.

Testing of pepper fruit for the presence of TYLCV. Fruits from TYLCV-infected pepper plants were tested using PCR for the presence of TYLCV. Mature fruits (based on size not color) were collected from TYLCV-infected plants from seven cultivars over a period of time of 129 to 187 days after inoculation. Fruits were selected at random. Fruit flesh and peduncle tissue was tested separately for the presence of TYLCV DNA using PCR. Fruit was collected from several noninoculated plants as negative controls.

Testing acquisition of TYLCV from pepper fruit. Forty to three hundred virus-free adult whiteflies were placed on individual fruit (collected from TYLCV-infected pepper plants) in cylindrical feeding chambers and allowed to feed for $12 \mathrm{~h}$. Tomato and/or D. stramonium seedlings were then introduced into the feeding chamber for a 72-h IAP, after which time the plants were treated with imidacloprid and moved to an insect-proof cage where they were monitored for the appearance of TYLCV symp- 
toms for 4 weeks. Multiple fruit from several cultivars were tested.

Field studies. Peppers are grown in Florida in open fields nearly year-round in southwest Florida, although most of the production occurs from August through June. Leaf samples were collected from every fourth plant in rows from five sites at research pepper plots in southwestern Florida during May 2005. Sites 1 and 2 were located approximately $48 \mathrm{~km}$ from sites 3, 4, and 5. Pepper plants varied in age and cultivar among the sites. Site 1 ('Grande') was in the field 10 weeks, site 2 ('Camelot') was in the field 10 weeks, site 3 ('Alliance') was in the field 8 weeks, site 4 ('Crusader') 4 weeks, and site 5 ('Ixtapa') 6 weeks. All cultivars except 'Ixtapa' were tested and found to be susceptible to TYLCV in greenhouse studies ('Ixtapa' was not tested) (Table 1). All research plots were located within $0.5 \mathrm{~km}$ of tomato research plots. Leaf samples were collected, frozen at $-50^{\circ} \mathrm{C}$, and tested for the presence of TYLCV using nucleic acid spot hybridization. Samples testing positive by dot spot hybridization were confirmed using PCR and only those samples positive in both assays were considered positive for TYLCV.

\section{RESULTS}

Screening Capsicum species and cultivars for susceptibility to TYLCV and TYLCV-Mld. Sixty-nine cultivars and experimental lines of peppers (C. annuum, $C$. baccatum, $C$. chinense, $C$. frutescens, and $C$. pubescens) were tested for susceptibility to TYLCV and/or TYLCV-Mld. Five to fourteen test plants per genotype were inoculated with TYLCV using 25 viruliferous whiteflies. In addition, four plants of each cultivar remained uninoculated and served as negative controls. In the event that inoculated plants remained free of virus, a second set of plants was inoculated with 100 whiteflies per plant. Whiteflies were allowed an IAP of 4 to 7 days. Inoculation with TYLCV-Mld was similar with the exception that adult whiteflies were added at a density of 25 to 50 whiteflies per plant.

At least one genotype from C. annuum, C. baccatum, C. chinense, and $C$. frutescens was susceptible to TYLCV (Tables 1 and 2). Only one genotype of $C$. pubescens was tested and was unable to be infected (Table 1). One of six genotypes of $C$. chinense, one of two genotypes of $C$. baccatum, and a single genotype of $C$. frutescens were able to be infected with TYLCV (Table 1). Approximately one-half of the C. annuum genotypes (27 of 55) tested were able to be infected with TYLCV (Table 2). The following cultivars of $C$. annuиm were tested but were unable to be infected: 'Aladdin X3R' (Seminis Vegetable Seeds), 'Aristotle X3R' (Seminis Vegetable Seeds), 'Double Up' (Sakata Seed America), 'El Jefe' (Sakata Seed America), 'Heritage HMX 1640'
(Ferry Morse), 'Hungarian Hot Wax' (Desert Seeds), 'Mulato Isleno' (Ball Seeds), 'Patriot HMX 640' (Harris Moran), 'Red Rooster', 'Sweet Banana' (Ferry Morse), 'Tiburon' (Sakata Seed America), 'Maor' and 1195 (Hazara Genetics) and the following entries in the Israeli gene bank: 58, 62, 756, 1598, 3016, 3526, 3537, 4751, 4590, PI 705, PI 723, PI 735, 9440, 9443, 'Orabella', and 'Overon'.

Some cultivars were not infected using the lower density of viruliferous whiteflies but were infected with TYLCV using the higher density (Table 2). In addition, some cultivars were infected at much higher frequencies than others. This suggests that there may be some differences among cultivars either in the ability of TYLCV to establish an infection and/or in feeding behaviors of the whitefly that affect transmission efficiency.

TYLCV-Mld was inoculated to five species of Capsicum (C. pubescens was not inoculated), including 19 genotypes of C. аnnuum (Table 1). Only one difference in host susceptibility was observed between TYLCV and TYLCV-Mld. $C$. chinense 'Guam Boonies' was susceptible to TYLCV but was not susceptible to TYLCV-Mld (Table 1).

None of the infected pepper plants of any species or genotype showed any evidence of TYLCV-induced symptoms either in the foliage or the fruit. There were no obvious effects on fruit size, fruit number, or time of fruit set on any TYLCV-infected pepper plants (data not shown). However, inoculated test plants did show a response to whitefly feeding. Leaves produced after inoculation showed mottling and bright yellowing of the small veins. These symptoms gradually decreased in intensity in leaves produced after the cessation of whitefly feeding (Fig. 1). This was observed in all genotypes tested.

Although TYLCV was readily detected in leaf samples collected from infected plants of $C$. апnиит 'California Wonder', this was not true for many of the genotypes. TYLCV was not detected in all leaves (produced after inoculation) collected from the same plant and assayed at the same time. This may or may not be the explanation for the observation that some plants did not remain positive but yielded conflicting results when assayed multiple times over a period of several months. These inconsistencies in detection were unexpected since this is unlike results obtained with other hosts of TYLCV (J. E. Polston, unpublished data). Therefore, plants testing negative were kept as much as 6 months and tested three to six times before being considered uninfected.

Detection of TYLCV in pepper plants: Field survey. TYLCV was readily detected in leaf samples of pepper plants collected at research plots in southwest Florida (Table 3). TYLCV was detected at frequencies of 54.6 to $100 \%$ in cultivars known to be susceptible to TYLCV. No TYLCV was detected in 'Ixtapa',

TABLE 1. Susceptibility of five Capsicum species to two strains of Tomato yellow leaf curl virus (TYLCV)

\begin{tabular}{|c|c|c|c|c|c|}
\hline \multirow[b]{3}{*}{ Genotype } & \multirow[b]{3}{*}{ Type or cultivar name } & \multirow[b]{3}{*}{ Source } & \multicolumn{3}{|c|}{ No. plants infected/no. plants inoculated } \\
\hline & & & \multicolumn{2}{|c|}{ TYLCV } & \multirow{2}{*}{$\begin{array}{c}\text { TYLCV-Mld } \\
\text { 25-50 Whiteflies/plant }\end{array}$} \\
\hline & & & 25 Whiteflies/plant & 100 Whiteflies/plant & \\
\hline C. annuum & 'California Wonder' (bell) & American Seed & $9 / 9$ & $\mathrm{NT}^{\mathrm{a}}$ & $5 / 7$ \\
\hline \multicolumn{6}{|l|}{ C. anпuиm var. } \\
\hline glabriusculum & Grove pepper (pequin) & Collected wild from Florida Keys & $2 / 14$ & NT & $1 / 7$ \\
\hline C. baccatum & (pea) & Terra Time and Tide & $3 / 14$ & NT & $4 / 14$ \\
\hline C. baccatum & 'Pen' (pea) & Israel Gene Bank & NT & $0 / 10$ & $0 / 10$ \\
\hline C. chinense & 'Sakata 11' (habanero) & Sakata Seed America & $0 / 14$ & $0 / 10$ & $0 / 10$ \\
\hline C. chinense & (habanero) & The Cook's Garden & $0 / 7$ & NT & NT \\
\hline C. chinense & Guam Boonies & Terra Time and Tide & $0 / 12$ & $18 / 20$ & $0 / 10$ \\
\hline C. chinense & PI 152225 (habanero) & Israel Gene Bank & NT & $0 / 10$ & $0 / 10$ \\
\hline C. chinense & 'CA4' (habanero) & Israel Gene Bank & NT & $0 / 10$ & $0 / 10$ \\
\hline C. chinense & Scotch Bonnet (habanero) & M. Roye, University West Indies & NT & $0 / 10$ & $0 / 10$ \\
\hline C. chinense & West Indian Red (habanero) & M. Roye, University West Indies & NT & $0 / 10$ & $0 / 10$ \\
\hline C. frutescens & 'Greenleaf strain hot' (tabasco) & Ball Seed & $2 / 14$ & NT & $1 / 8$ \\
\hline C. pubescens & 'Sakata 12' (rocoto) & Sakata Seed America & $0 / 14$ & NT & NT \\
\hline
\end{tabular}

a NT $=$ not tested. 
however, this cultivar was not tested in greenhouse experiments so it is possible that it is not susceptible to TYLCV.

Detection of TYLCV in pepper fruit. TYLCV DNA was detected in fruit flesh and peduncles of some, although not all, fruit from infected plants (Table 4). Fruit from uninfected plants was used as negative controls in detection assays and no false positives were observed (data not shown). TYLCV was detected in approximately $75 \%$ of the fruit sampled from seven cultivars of C. annuum. TYLCV was not detected in all fruit on a plant and was not evenly distributed in the flesh and peduncle/calyx of fruit. TYLCV was detected in only the peduncle/calyx of approximately $25 \%$ of fruit, in only the flesh in $33 \%$ of fruit, and was detected in both the peduncle/calyx and flesh of $42 \%$ of the fruit (data not shown). TYLCV was detected in fruit as early as 55 days and as long as 289 days after inoculation (the last day that a fruit was collected) (data not shown).

TYLCV acquisition and transmission from infected pepper plants and fruit. Since these studies indicated that TYLCV and TYLCV-Mld were able to infect some pepper genotypes and field-grown pepper plants in Florida were found infected with TYLCV, it was imperative to determine whether whiteflies could acquire TYLCV or TYLCV-Mld from infected pepper plants to demonstrate the ability of pepper plants to serve as viral reservoirs. In greenhouse trials, the following pepper genotypes found able to serve as sources of TYLCV for whitefly acquisition and transmission: C. annuum 'California Wonder' and 'HAY100', C. chinense 'Guam Boonies', C. baccatum, and C. frutescens 'Tabasco greenleaf strain hot' (data not shown). C. annuum 'California Wonder' and 'HAY100' were demonstrated to serve as acquisition sources of TYLCV-Mld for transmission to tomato.

The transmission efficiency of whiteflies acquiring TYLCV from infected pepper was compared with that of infected tomato plants. 'California Wonder' pepper plants were inoculated with TYLCV and infection was confirmed 3 weeks after inoculation using PCR. Nonviruliferous whiteflies were allowed to feed on the infected pepper plants. As a comparison, whiteflies were allowed to feed on TYLCV-infected tomato plants ('Rehovot-13', a Marmande type tomato). Transmission efficiency was determined by inoculating tomato test plants using clip cages containing 10 viruliferous whiteflies per cage. These experiments were conducted four separate times. Using this approach, the efficiency of acquisition from tomato plants was found to range from 50 to $80 \%$ with a mean of $70 \%$ (Table 5). The transmission efficiency from pepper plants ranged from 20 to $80 \%$ with a mean of $55 \%$. The mean transmission efficiency from pepper was only slightly lower than that of tomato. However, when higher numbers of whiteflies per plant were used and allowed to feed freely ("free choice") on tomato test plants, transmission rates reached $100 \%$

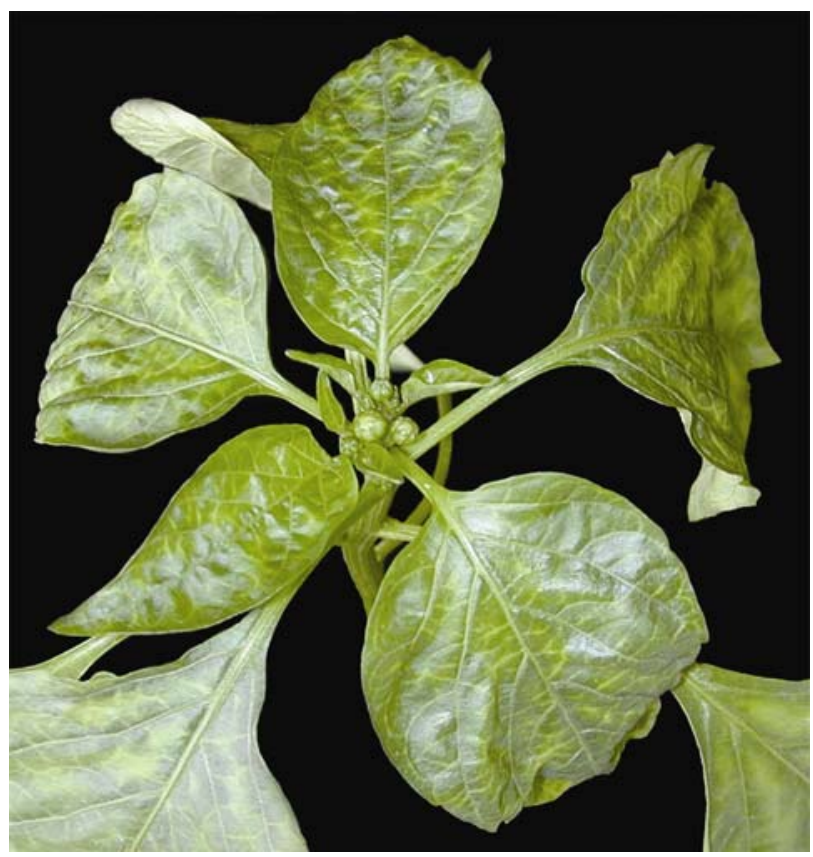

Fig. 1. Whitefly feeding damage in Capsicum annuum 'California Wonder' that appeared within 2 to 3 weeks after the addition of 25 adults of Bemisia tabaci biotype B.

TABLE 2. Susceptibility of Capsicum annuum cultivars and genotypes to Tomato yellow leaf curl virus ${ }^{\mathrm{a}}$

\begin{tabular}{|c|c|c|c|c|}
\hline \multirow[b]{2}{*}{ Cultivar/genotype } & \multirow[b]{2}{*}{ Fruit type } & \multirow[b]{2}{*}{ Source } & \multicolumn{2}{|c|}{ No. plants infected/no. plants inoculated } \\
\hline & & & 25 Whiteflies/plant & 100 Whiteflies/plant \\
\hline Anaheim Chili & Elongated cone & Ferry Morse & $0 / 14$ & $4 / 10$ \\
\hline Brigadier & Bell, green & Rogers/Syngenta Seeds & $3 / 14$ & $\mathrm{NT}^{\mathrm{b}}$ \\
\hline California Wonder & Bell, green & American Seed & $9 / 9$ & NT \\
\hline California Wonder300TMR & Bell, green & Ferry Morse & $2 / 14$ & NT \\
\hline Camelot X3R & Bell, green & Seminis Vegetable Seeds & $2 / 14$ & NT \\
\hline Cascabella & Hot, cone (Mirasol) & Ferry Morse & $2 / 14$ & NT \\
\hline Crusader & Bell, green & Rogers/Syngenta & $5 / 14$ & NT \\
\hline El Rey & Jalapeno & Sakata Seed America & $0 / 14$ & $1 / 10$ \\
\hline FPP2013 & Bell, green-red & Sakata Seed America & $1 / 14$ & NT \\
\hline FPP2014 & Bell, green-red & Sakata Seed America & $2 / 14$ & NT \\
\hline HAY 100 & Bell & Hazera Genetics & NT & $10 / 10$ \\
\hline Long Hot & Cayenne & Seminis Vegetable Seeds & $1 / 14$ & NT \\
\hline Olympus & Bell, green-red & Enza Zaden & $3 / 14$ & NT \\
\hline Orion & Bell, green & Enza Zaden & $2 / 14$ & NT \\
\hline Grande & Jalapeno & Seminis Veg. Seeds & $6 / 14$ & NT \\
\hline SCM334 & Wild serrano & Sakata Seed America & $0 / 14$ & $5 / 10$ \\
\hline Senorita & Red "cheese" & Sakata Seed America & $0 / 14$ & $4 / 10$ \\
\hline Sentry & Bell, green-red & Rogers/Syngenta Seeds & $0 / 14$ & NT \\
\hline SCM334 & Wild serrano & Sakata Seed America & $0 / 14$ & $5 / 10$ \\
\hline Serrano & Serrano & Terra Time and Tide & $4 / 10$ & NT \\
\hline SPP0132 & Bell,green-orange & Sakata Seed America & $2 / 14$ & NT \\
\hline Stiletto & Bell, red & Rogers/Syngenta Seeds & $1 / 14$ & NT \\
\hline Twist Sweet & Hot & YuAnFarms (Korea) & $3 / 14$ & NT \\
\hline Wizard X3R & Bell, green & Seminis Vegetable Seeds & $1 / 14$ & NT \\
\hline XPP0701 & Anaheim & Sakata Seed America & $1 / 5$ & NT \\
\hline 769 & Bell & Hazera Genetics & NT & $1 / 10$ \\
\hline
\end{tabular}

a Florida isolate of Tomato yellow leaf curl virus.

b NT $=$ not tested. 
whether acquisition was from TYLCV-infected pepper or tomato plants (Table 5).

Whiteflies were unable to acquire TYLCV or TYLCV-Mld from pepper fruit and transmit to tomato plants. Whiteflies were observed to cluster on peduncles and calyxes of pepper fruit. Regardless of whether fruit was from infected or healthy pepper, whiteflies from the Florida culture were dead within $12 \mathrm{~h}$ after placement on pepper fruit. However, some whiteflies from the Volcani culture survived the 12-h AAP on pepper fruit and were subsequently moved to tomato for an IAP. Nonetheless, no TYLCV transmission to tomato was observed following feeding on fruit. Therefore, pepper fruit are unlikely to serve as sources of TYLCV.

\section{DISCUSSION}

We have inoculated a number of different $C$. annuum accessions with TYLCV using whiteflies. Our results indicate that although pepper is a host for TYLCV, no viral-induced symptoms were observed in any of the tested $C$. annuum accessions. These results are in agreement with the recent results of Morilla et al. (12) who demonstrated that pepper is a symptomless host for two TYLCV strains. Although pepper species were symptomless hosts for TYLCV, they did develop clear and pronounced whiteflyinduced symptoms following feeding by either nonviruliferous or viruliferous whiteflies.

This is the first study that reports on the susceptibility of at least one genotype of $C$. baccatum, $C$. chinense, and $C$. frutescens to TYLCV and the susceptibility of at least one genotype of $C$. baccatum and $C$. frutescens to TYLCV-Mld. Results demonstrate that some, but not all, cultivars of $C$. annuum, C. baccatum, and C. chinense could be infected by TYLCV. This is unlike TYLCV susceptibility in L. esculentum in which all genotypes tested were

TABLE 3. Detection of Tomato yellow leaf curl virus ${ }^{\mathrm{a}}$ (TYLCV) using polymerase chain reaction in field plots of five cultivars of Capsicum annuиm

\begin{tabular}{llcc}
\hline Site & Cultivar & No. plants sampled & Positive (\%) for TYLCV \\
\hline 1 & Grande & 11 & 55 \\
2 & Camelot & 7 & 100 \\
3 & Alliance & 24 & 58 \\
4 & Crusader & 46 & 72 \\
5 & Ixtapa & 69 & 0 \\
\hline
\end{tabular}

a Florida isolate of Tomato yellow leaf curl virus.

TABLE 4. Detection of Tomato yellow leaf curl virus (TYLCV) in fruit of TYLCV-infected Capsicum annuum

\begin{tabular}{llc}
\hline Isolate of TYLCV & \multicolumn{1}{c}{ Cultivar } & $\begin{array}{c}\text { No. positive fruit/ } \\
\text { fruit tested/plant }\end{array}$ \\
\hline Florida & California Wonder & $1 / 1$ \\
Volcani & California Wonder & $2 / 2$ \\
Florida & El Rey & $0 / 3$ \\
Florida & Wild Serrano & $4 / 6,2 / 3,1 / 1^{\mathrm{a}}$ \\
Florida & Anaheim chili & $5 / 5,4 / 5$ \\
Florida & Stiletto & $2 / 3$ \\
Florida & Patriot & $3 / 3$ \\
Volcani & HAY100 & $1 / 1$ \\
\hline
\end{tabular}

${ }^{a}$ Fruit collected from three different plants, results of each plant shown. susceptible $(4,26)$, but similar to that of Phaseolus vulgaris in which only $57 \%$ of the genotypes tested were susceptible to TYLCV (9). Some genotypes were infected at much higher rates than others while other genotypes only became infected at the higher density of viruliferous whiteflies. This suggests that there may be some differences among genotypes either in the ability of TYLCV to establish an infection and/or in feeding behaviors of the whitefly that affect transmission efficiency. This lack of complete susceptibility and differences in ease of establishment of TYLCV infection among genotypes may explain many of the discrepancies in the literature regarding the status of $C$. annuиm as a host and reservoir of TYLCV.

These results establish the ability of $C$. annuum as well as three other Capsicum species to serve as sources of TYLCV for tomato. This is in contrast with the results of Morilla et al. (12) who reported that whiteflies were unable to acquire and transmit TYLCV-[Alm] and TYLCV-Mld from pepper to tomato. In addition, they detected low frequencies of TYLCV in pepper plants in commercial greenhouses. Thus, they concluded that pepper was a dead-end host in the disease cycle of TYLCV. Our results demonstrate that plants of at least one cultivar each of $C$. annuum, $C$. baccatum, $C$. chinense, and $C$. frutescens were able to serve as sources of TYLCV for tomato with $B$. tabaci biotype B as a vector. When using only 10 whiteflies per plant for inoculation access feeding, the efficiency of $C$. annuum plants to serve as TYLCV source plants was somewhat lower than that of tomato plants which contrasts with the absence of acquisition from C. annuum as reported by Morilla et al. (12). When higher numbers of whiteflies (25 to 50) per plant were used and the whiteflies were not confined in clip cages, transmission efficiencies increased to as high as $100 \%$ from both $C$. annuum and tomato plants. This suggests that whiteflies in the field would be able to acquire TYLCV from pepper. The discrepancies between our results and those of Morilla et al. (12) may be due to differences in cultivars used in the experiments. We observed that not all pepper cultivars were able to be infected. In addition, we observed that some cultivars only became infected when inoculated with the greater numbers of viruliferous whiteflies. In addition, differences in results may be due to biological differences in whitefly biotypes. Whitefly transmission studies in Spain were conducted with the Q biotype, while these studies were conducted with the $\mathrm{B}$ biotype. It is possible that biotype Q and B could differ in their feeding behavior on pepper and this could be reflected in differences in ability to acquire TYLCV from pepper.

Although plants of $C$. annuum were able to serve as sources of TYLCV and TYLCV-Mld, whiteflies were unable to transmit virus from fruit of infected pepper plants to tomato seedlings. These results indicate that pepper fruit are unlikely sources of TYLCV, in contrast to results of similar studies of tomato fruit (6).

The small field survey demonstrated that pepper plants were able to be infected in the field. The only plot in which TYLCV was not detected was that of a pepper cultivar whose susceptibility to TYLCV had not been previously evaluated in the greenhouse. Frequencies of TYLCV-infected plants were much higher in pepper than those found in most commercial tomato fields in southwest Florida. This could be due to the fact that whitefly management is practiced rigorously in both commercial and research fields of tomato but almost never in pepper fields.

TABLE 5. Comparison of pepper and tomato as acquisition hosts for Tomato yellow leaf curl virus ${ }^{\mathrm{a}}$ by Bemisia tabaci biotype B

\begin{tabular}{|c|c|c|c|c|c|}
\hline \multirow[b]{2}{*}{ Source plant } & \multirow[b]{2}{*}{ No. source plants tested } & \multirow[b]{2}{*}{ Type of transmission } & \multirow[b]{2}{*}{ No. tomato seedlings inoculated } & \multicolumn{2}{|c|}{ Transmission $(\%)$} \\
\hline & & & & Range & Mean \\
\hline Tomato & 8 & Clip cage & 80 & $50-100$ & 71 \\
\hline Pepper & 8 & Clip cage & 80 & $20-80$ & 46 \\
\hline Pepper & 6 & Free feeding & 60 & $60-100$ & 85 \\
\hline
\end{tabular}

a Volcani isolate of TYLCV. 
This work implicates the role of pepper plants in the epidemiology of TYLCV. Peppers are often grown at the same time and in close proximity with tomatoes, and many whitefly populations, including those of southwest Florida, are able to feed and reproduce on peppers as well as on tomatoes (25). Greenhouse experiments demonstrated that transmission efficiency was similar between tomato and at least one cultivar of $C$. annuum. On the basis of these data, it is highly probable that some pepper cultivars are able to serve as reservoirs of TYLCV.

These findings have clear implications for the management of TYLCV in tomatoes in areas where peppers and the B biotype of the whitefly are present. Growers should be able to reduce TYLCV spread from peppers to tomatoes by improving the management of whiteflies in susceptible pepper cultivars and by choosing TYLCV-resistant pepper cultivars for production in fields near those of tomato.

\section{ACKNOWLEDGMENTS}

This work was supported in part by the Florida Agricultural Experiment Station, a grant from the Florida Fruit and Vegetable FoundationCooperative Production Research Specialty Projects, and by Postdoctoral Award No. FR 16-2003 from BARD (The United States-Israel Binational Agricultural Research and Development Fund).

\section{LITERATURE CITED}

1. Al-Musa, A. 1982. Incidence, economic importance, and control of tomato yellow leaf curl in Jordan. Plant Dis. 66:561-563.

2. Antignus, Y., and Cohen, S. 1994. Complete nucleotide sequence of an infectious clone of a mild isolate of tomato yellow leaf curl virus (TYLCV). Phytopathology 84:707-712.

3. Brown, J. K., Idris, A. M., Torres-Jerez, I., Banks, G. K., and Wyatt, S. D. 2001. The core region of the coat protein gene is highly useful for establishing the provisional identification and classification of begomoviruses. Arch. Virol. 146:1581-1598.

4. Cohen, S., and Antignus, Y. 1994. Tomato yellow leaf curl virus, a whitefly-borne geminivirus of tomatoes. Pages 259-288 in: Advances in Disease Vector Research. Vol 10. Springer-Verlag, NY.

5. Cohen, S., and Nitzany, F. E. 1966. Transmission and host range of the tomato yellow leaf curl virus. Phytopathology 56:1127-1131.

6. Delatte, H., Dalmon, A., Rist, D., Soustrade, I., Wuster, G., Lett, J. M., Goldbach, R. W., Peterschmitt, M., and Reynaud, B. 2003. Tomato yellow leaf curl virus can be acquired and transmitted by Bemisia tabaci (Gennadius) from tomato fruit. Plant Dis. 87:1297-1300.

7. Dellaporta, S. L., Wood, J., and Hicks, J. B. 1983. A plant DNA minipreparation: Version II. Plant Mol. Biol. Rep. 1:19-21.

8. Hilje, L., Costa, H. S., and Stansly, P. A. 2001. Cultural practices for managing Bemisia tabaci and associated viral diseases. Crop Prot. 20:801-812.

9. Lapidot, M. 2002. Screening common bean (Phaseolus vulgaris) for resistance to Tomato yellow leaf curl virus. Plant Dis. 86:429-432.

10. Lapidot, M., and Friedman, M. 2002. Breeding for resistance to whiteflytransmitted geminiviruses. Ann. Appl. Biol. 140:109-127.

11. Mansour, A., and Al-Musa, A. 1992. Tomato yellow leaf curl virus: Host range and virus-vector relationships. Plant Pathol. 41:122-125.

12. Morilla, G., Janssen, D., García-Andrés, S., Moriones, E., Cuadrado, I. M., and Bejarano, E. R. 2005. Pepper (Capsicum annuиm) is a dead-end host for Tomato yellow leaf curl virus. Phytopathology 95:1089-1097.
13. Moriones, E., and Navas-Castillo, J. 2000. Tomato yellow leaf curl virus, an emerging virus complex causing epidemics worldwide. Virus Res. 71:123-134.

14. Navas-Castillo, J., Sánchez-Campos, S., Díaz, J. A., and Moriones, E. 1997. First report of Tomato Yellow Leaf Curl Virus-Is in Spain: Coexistence of two different geminiviruses in the same epidemic outbreak. Plant Dis. 81:1461.

15. Navas-Castillo, J., Sánchez-Campos, S., Díaz, J. A., Saez-Alonso, E., and Moriones, E. 1999. Tomato yellow leaf curl virus-Is causes a novel disease of common bean and severe tomato epidemics in Spain. Plant Dis. 83:29-32.

16. Navas-Castillo, J., Sanchez-Campos, S., Noris, E., Lourno, D., Accotto, G. P., and Moriones, E. 2000. Natural recombination between Tomato yellow leaf curl virus-Is and Tomato leaf curl virus. J. Gen. Virol. 81:27972801.

17. Navot, N., Pichersky, E., Zeidan, M., Zamir, D., and Czosnek, H. 1991. Tomato yellow leaf curl virus: A whitefly-transmitted geminivirus with a single genomic component. Virology 185:151-161.

18. Polston, J. E., and Anderson, P. K. 1997. The emergence of whiteflytransmitted geminiviruses in tomato in the western hemisphere. Plant Dis. 81:1358-1369.

19. Polston, J. E., Rosebrock, T. R., Sherwood, T., Creswell, T., and Shoemaker, P. J. 2002. Appearance of Tomato yellow leaf curl virus in North Carolina. Plant Dis. 86:73.

20. Quinones, M., Fonseca, D., Martinez, Y., and Accotto, G. P. 2002. First report of Tomato yellow leaf curl virus infecting pepper plants in Cuba. Plant Dis. 86:73.

21. Reina, J., Morilla, G., Bejarano, E. R., Rodríguez, M. D., and Janssen, D. 1999. First report of Capsicum annuum plants infected by tomato yellow leaf curl virus. Plant Dis. 83:1176.

22. Rojas, M. R., Gilbertson, R. L., Russell, D. R., and Maxwell, D. P. 1993. Use of degenerate primers in the polymerase chain reaction to detect whitefly-transmitted geminiviruses. Plant Dis. 77:340-347.

23. Roye, M. E., Wernecke, M. E., McLaughlin, W. A., Nakhla, M. K., and Maxwell, D. P. 1999. Tomato dwarf leaf curl virus, a new bipartite geminivirus associated with tomatoes and peppers in Jamaica and mixed infection with tomato yellow leaf curl virus. Plant Pathol. 48:370-378.

24. Salati, R., Nahkla, M. K., Rojas, M. R., Guzman, P., Jaquez, J., Maxwell, D. P., and Gilbertson, R. L. 2002. Tomato yellow leaf curl virus in the Dominican Republic: Characterization of an infectious clone, virus monitoring in whiteflies, and identification of reservoir hosts. Phytopathology 92:487-496.

25. Schuster, D. J., Thompson, S., and Gilreath, P. R. 2003. What's up with all these whiteflies? Pages 12-19 in: Proc. Florida Tomato Inst. PRO520.

26. Scott, J. W., Stevens, M. R., Barten, J. H. M., Thome, C. H., Polston, J. E., and Schuster, D. J. 1995. Introgression of resistance to whitefly geminiviruses from Lycopersicon chilense to tomato. Pages 357-367 in: Bemisia: Taxonomy, Biology, Damage, Control, and Management. Intercept Press, Andover, UK.

27. Sinisterra, X., Patte, C. P., Siewnath, S., and Polston, J. E. 2000. Identification of Tomato yellow leaf curl virus-Is in The Bahamas. Plant Dis. $84: 592$.

28. Ucko, O., Cohen, S., and Ben-Joseph, R. 1998. Prevention of virus epidemics by a crop-free period in the Arava region of Israel. Phytoparasitica 26:313-321.

29. Valverde, R. A., Lotrakul, P., Landry, A. D., and Boudreaux, J. E. 2001. First report of Tomato yellow leaf curl virus in Louisiana. Plant Dis. $85: 230$.

30. Wyatt, S. D., and Brown, J. K. 1996. Detection of subgroup III geminivirus isolates in leaf extracts by degenerate and polymerase chain reaction. Phytopathology 86:1288-1293. 